\title{
A new approach to paleoreconstruction of Gusinoe Lake sediments: lipid biomarker analysis
}

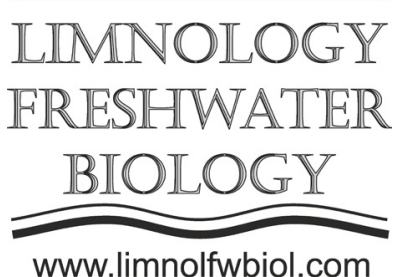

\author{
Nikitina E.P.*, Pintaeva E.Ts. \\ Baikal Institute of Nature Management, Siberian Branch, Russian Academy of Sciences, Sakhyanovoy Str., 6, Ulan-Ude, 670047, Russia
}

\begin{abstract}
Lakes are important paleoenvironmental archives retaining abundant information due to their typical high sedimentation rates and susceptibility to environmental changes. Here, we present first results from lipid biomarker investigations of Gusinoe Lake sediments using gas chromatography (GC) and GC-mass-spectrometry. In total, 91 components were identified in the lipid fraction, including saturated, unsaturated, branched and hydroxy fatty acids, fatty alcohols, dicarboxylic acids, aldehydes, sterols and alicyclic compounds. The main lipid biomarkers and their ratios showed the contribution of bacteria, plankton and terrestrial higher plants to the organic matter of bottom sediments of Lake Gusinoe. The distribution of the carbon preference index (CPI) in the core of bottom sediments of Lake Gusinoe testifies to the transition from cold and dry (lower core layers) to warm and humid climatic conditions. This study illustrates potential of lipid biomarkers as paleoclimate and paleoenvironment proxies.
\end{abstract}

Keywords: Lake Gusinoe, bottom sediments, lipid biomarkers, fatty acids, paleoreconstruction

\section{Introduction}

Lake bottom sediments are natural archives, storing information about the evolution of the lake. They are an important source of data on the climatic, geochemical, and environmental conditions that existed in the catchment area and in the reservoir itself. Thus, lakes are important paleoenvironmental archives of short-term processes at local to regional scales. Currently, there are several approaches for paleoreconstruction of lake bottom sediments. One of them is the use of various paleoindicators, in particular lipid biomarkers. Features of the structure and biosynthesis of fatty acids and lipids served as the basis for their wide application as biomarkers for the assessment of the origin and transformation of organic matter (Hu et al., 2006; Holtvoeth et al., 2010). Furthermore, lipid biomarkers have been widely used to reconstruct paleoenvironments and changes in lacustrine systems (Ishiwatari et al., 2006; Arts et al., 2009; Ouyang et al., 2015). The aim of the current study was to determine paleoenvironmental changes reflected in lipid biomarkers in a bottom sediment in Lake Gusinoe (Western Transbaikalia, Russia).

\section{Material and methods}

The 54-cm-long column was taken in March 2018 in the middle of Lake Gusinoe. A $1.5 \mathrm{~m}$ corer invented at the State Oceanographic Institute (TG-1.5) was used for sampling bottom sediments. Lipid components were extracted in layers (every $3 \mathrm{~cm}$ ) by the method of acid methanolysis in a $\mathrm{HCl} /$ methanol solution for one hour at $80^{\circ} \mathrm{C}$. The chromatograms of acid methanolysis products of bottom sediments obtained in the continuous scanning mode were analyzed, using the standard NIST 11.L program of an AT-6890/5973N gas chromatograph (Pintaeva, 2019).

\section{Results and Discussion}

In total, 91 compounds were identified in lipid fraction of sediments. The major components of lipid fraction were saturated fatty acids (25.51$81.64 \%$ of total lipids), followed by fatty alcohols (13.44-54.12\%), hydroxy fatty acids (3.15-18.72\%) and monounsaturated straight-chain and branched fatty acids (0.97-20.64\%). Also, dicarboxylic acids, aldehydes, sterols and alicyclic compounds are found as minor components.

Although most lipid biomarkers are non-specific, previous studies (Camacho-Ibar et al., 2003; Holtvoeth et al., 2010) have shown that some of the fatty acids, as well as their ratios, can provide information about the origin of organic matter in bottom sediments. The following markers exist for assessing the contribution of bacteria, plankton (phyto- and zooplankton) and terrestrial higher plants to the organic matter of 
bottom sediments (Camacho-Ibar et al., 2003): $\Sigma$ Bact $=\mathrm{i} 15: 0+\mathrm{a} 15: 0+\mathrm{i} 17: 0+\mathrm{a} 17: 0 ;$ PPlank $=16: 1 \omega 7$ $+\operatorname{PUFAs}(20: 5+20: 4)+\operatorname{PUFAs}(22: 6+22: 5) ; \quad \Sigma$ Terri $=24: 0+26: 0+28: 0+30: 0$. The marker evaluating the contribution of the bacterial community to bottom sediments ranged from 0.13 to $4.45 \%$ and decreased with depth. The plankton marker (0.08-1.77\%) also decreased with the depth and was not detected deeper than $33 \mathrm{~cm}$. The marker of terrestrial higher plants (3.49-23.46\%), on the contrary, tended to increase with the maximum at a depth of $39-42 \mathrm{~cm}$.

One of the important indicators is carbon preference index (CPI), the ratio of even-over-odd numbered carboxylic compounds. CPI is used to reconstruct paleoclimate and paleoenvironment, including temperature, humidity and dominant sources of related lipids. The reconstruction of paleoclimatic archives via CPI derives from the variation of diagenesis and degradation rates with climatic conditions. Under dry and cold climates, microbial diagenesis and degradation of organic material are reduced, corresponding to a high CPI value, while the accelerated microbial diagenesis and degradation of organic matter result in a low CPI value under a wet and warm climate (Xie et al., 2004; Zhou et al., 2005). The CPI in the analyzed core increases with depth, which testifies to the transition from cold and dry (lower core layers) to warm and humid climatic conditions. It is possible that the deep layers of the column were formed in the period prior to 1862 , when the sampling site was not yet flooded. This will be completely clear after dating, and the results obtained by the present time may be correlated with the history of the evolution of Gusinoe Lake.

\section{Conclusions}

This study illustrates the potential of lipid biomarkers as paleoclimate and paleoenvironment proxies. Lipid molecular proxies in combination with molecular distribution of $\mathrm{n}$-alkanes, $\mathrm{dD}$ or $\mathrm{D} / \mathrm{H}$ ratios, palynological studies, etc. can be applied to reconstruct the past precipitation, temperature and humidity. The results of this study show the compatibility of different lipid biomarkers in assessing the origin of organic matter.

\section{Acknowledgments}

Research was carried out within the framework of the State assignment of Baikal Institute of Nature Management of SB RAS and with partial financial support from the Ministry of Science and Higher Education (project no. 2020-1902-01-071).

\section{References}

Arts M.T., Brett M.T., Kainz M.J. 2009 Lipids in Aquatic Ecosystems. New York: Springer Dordrecht Press. DOI: 10.1007/978-0-387-89366-2

Camacho-Ibar V.F., Aveytua-Alcázar L., Carriquiry J.D. 2003. Fatty acid reactivities in sediment cores from the northern Gulf of California. Organic geochemistry 34(3): 425-439.

Holtvoeth J., Vogel H., Wagner B., et. al. 2010. Lipid biomarkers in Holocene and glacial sediments from ancient Lake Ohrid (Macedonia, Albania). Biogeosciences 7: 3473-3489.

Hu J., Zhang H., Peng P. 2006. Fatty acid composition of surface sediments in the subtropical Pearl River estuary and adjacent shelf, Southern China. Estuarine Coastaland Shelf Science 66: 346-356.

Ishiwatari R., Yamamoto S., Uemura H. 2005. Lipid and lignin/cutin compounds in lake Bakal sediments over the last 130 kyr: implications for glacial-interglacial palaeoenvironmental change. Organic geochemistry 36: 327-347.

Ouyang X., Guo F, Bu H. 2015. Lipid biomarkers and pertinent indices from aquatic environment record paleoclimate and paleoenvironment changes. Quaternary Science Reviews 123: 180-92. DOI: $10.1016 / \mathrm{j}$. quascirev.2015.06.029

Pintaeva E.Ts. 2019. Lipid biomarkers in paleoreconstruction of lake sedimentogenesis. In: IOP Conference Series: Earth and Environmental Science 320: 012016. DOI:10.1088/1755-1315/320/1/012016

Xie S., Nott C.J., Avsejs L.A. et al. 2004. Molecular and isotopic stratigraphy in an ombrotrophic mire for paleoclimate reconstruction. Geochimica et Cosmochimica Acta 68: 2849-2862.

Zhou W.J., Xie S.C., Meyers P.A., et al. 2005. Reconstruction of late glacial and Holocene climate evolution in southern China from geolipids and pollen in the Dingnan peat sequence. Organic Geochemistry 36: 1272-1284. 